\title{
Exploring the awareness level of biomedical waste management: Case of Indian healthcare
}

\author{
Rahul S. Mor*, Sarbjit Singh, Arvind Bhardwaj and Mohammad Osama
}

Department of Industrial \& Production Engineering, National Institute of Technology, Jalandhar, Punjab, India

C H R O N I C L E

Article history:

Received: February 1, 2017

Received in revised format: July

6, 2017

Accepted: July 31, 2017

Available online:

July 31,2017

Keywords:

Biomedical waste (BMW)

descriptive statistics analysis

Healthcare facilities

Pollution

Disposal of waste

Hospital management

\section{A B S T R A C T}

\begin{abstract}
This study aims to investigate the awareness level of Biomedical waste managements in healthcare facilities, and their perception among hospital waste management team, doctors, nurses, lab technicians and waste handlers in Northwest Delhi region in India. The study has been conducted through a questionnaire survey followed by the descriptive statistical analysis method. Questionnaire contains of 38 questions, where the first section deals with the hospital waste management team, the second section is for doctors, nurses and lab technicians, and the third section is for the waste handlers. Out of 311 respondents, there were 16 hospital waste management teams, 81 doctors, 92 nurses, 49 lab technicians and 73 waste handlers. It was surprising that only $40 \%(n=10)$ hospitals had any kind of waste treatment \& disposal facility onsite, only $10 \%$ hospitals were using the latest technology and $60 \%$ hospitals shred the Biomedical waste before disposal. It was good to see that none of the hospital waste managements disposed the waste with general waste, and $40 \%$ of them were exhausting through government agencies and the remaining $60 \%$ were using private agencies to dispose the waste. Finally, all the hospitals maintained the record of waste generated. It is concluded that there was a lack of awareness about the biomedical waste generation, legislation and management among healthcare personnel, and they all needed regular audits and training programs at all levels, and a proper management starting from waste generation to its disposal at sites.
\end{abstract}

\section{Introduction}

The word 'biomedical waste' is any waste that is produced during analysis, treatment or vaccination of human beings or animals, or in the study activities applied to or in the invention or testing of biological, and covers the classes mentioned in schedule- 1 of govt. of India rules 1998 (Acharya et al., 2000; Alagoz et al., 2008). WHO evaluated that only $20 \%$ of total healthcare waste is infectious or and dangerous to human health and environment (Almuneef et al., 2003). The threats of bio-medical waste can cause numerous health diseases like respiratory, skin infections, gastroenteritis, HIV/AIDS, hepatitis, etc. Further, it causes contamination of land and water, and when treated by open burning or burning in burners it releases harmful gases that causes to environmental pollution (Ashtekar et al., 2004). Studies conclude that approximately 2 million new hepatitis ' $C$ ' cases, 4 million new hepatitis

\footnotetext{
* Corresponding author.

E-mail address: iersmor@gmail.com (R. S. Mor) 
'B' cases and 30000 HIV positive cases happen every year due to needle prick injuries in India (Ashkarian et al., 2004). Most of the doctors working in private medicals rural areas are renowned to use injections and IV fluids (Basu et al., 2012). Hazardous practices like reuse of syringes (with/without cleansing) and multi dose vessels increase the risk of blood borne viral syndromes. Bio-medical waste (BMW) management is still in its beginning stage globally, and there seems to be numerous misperception with BMW management among the operatives, generators, decision-makers and general community. This may be because of the lack of awareness. Hence, all the resource people concerned with BMW like hospital managers, nurses, physicians, consultants, paramedical staff and waste retrievers etc. need to be studied (Bdour et al., 2007; Chitnis et al., 2000). A report by Indian Institute of Management, Lucknow revealed that only $50-55 \%$ of biomedical waste produced in the country is being well isolated, transported and disposed-off, whereas the rest generally ends up with the general waste. It is estimated that approx. 0.33 million tons of hospital waste is generated in India and this ranges from 0.5 to $2 \mathrm{~kg}$ per bed per day (GOI, MoHFW, 2002). In developing countries like India, waste is dumped generally in a most insanitary way, and new healthcare institutions are constructed without any attention of waste handling \& management. In the medical colleges and government hospitals, staffs are responsible for bio-waste management, but this duty goes to the doctor in-charge of the facility in small private nursing homes. Unless these doctors are aware about BMW, these small clinics will remain a threat to public health. Hence, this study is aimed to assess the awareness level and practices regarding biomedical waste management among medical practitioners in Northwest Delhi region in India.

\subsection{Categories of Biomedical wastes}

Given below are the various categories of Biomedical wastes (Table- 1).

Table 1

Categories of Biomedical wastes

\begin{tabular}{|c|c|c|}
\hline Waste & Waste Class and Description & $\begin{array}{l}\text { Treatment and Disposal } \\
\text { [Option] }\end{array}$ \\
\hline No. 1 & Human Anatomical Wastes i.e. Human tissues, organs, waste body parts & Incineration / deep burial \\
\hline No. 2 & $\begin{array}{l}\text { Animal Wastes i.e. animal tissue, organs, body parts, carcasses, body fluid, } \\
\text { blood and blood products, items contaminated with blood and fluids, wastes } \\
\text { from surgery treatment and autopsy and wastes of experimental animals used in } \\
\text { research, and the waste generated by veterinary hospitals, colleges, animal } \\
\text { houses and livestock farms }\end{array}$ & Incineration / deep burial \\
\hline No. 3 & $\begin{array}{l}\text { Microbiology \& Biotechnology Waste i.e. wastes from laboratory, culture } \\
\text { stocks or specimens of micro-organisms, live or attenuated vaccines, human and } \\
\text { animal cell culture used in research and infectious agents from research and } \\
\text { industrial laboratories, wastes from production of biological dishes and devices } \\
\text { used for transfer of cultures etc. }\end{array}$ & $\begin{array}{l}\text { Local autoclaving / microwaving/ incin- } \\
\text { eration }\end{array}$ \\
\hline No. 4 & $\begin{array}{l}\text { Waste Sharps i.e. Needles, syringes, scalpels, blades, glass, etc. that is capable } \\
\text { of causing puncture and cuts. This includes both used and unused sharps }\end{array}$ & $\begin{array}{l}\text { Disinfection using chemical treatment/ au- } \\
\text { toclaving/ microwave, shredding and dis- } \\
\text { posal in landfill/ recycling (for PVC and } \\
\text { plastics) }\end{array}$ \\
\hline No. 5 & $\begin{array}{l}\text { Discarded Medicines i.e. wastes comprising of outdated, contaminated and dis- } \\
\text { carded medicines }\end{array}$ & $\begin{array}{l}\text { Incineration or destruction and disposal in } \\
\text { landfills }\end{array}$ \\
\hline No. 6 & $\begin{array}{l}\text { Soiled Wastes i.e. wastes generated from soiled cotton, dressings, plaster casts, } \\
\text { linens, beddings, material contaminated with blood including the packaging ma- } \\
\text { terials }\end{array}$ & Incineration autoclaving/ microwaving \\
\hline No. 7 & $\begin{array}{l}\text { Solid Waste i.e. wastes generated from disposable items other than the waste } \\
\text { sharps such as tubing's, catheters, intravenous sets etc. }\end{array}$ & $\begin{array}{l}\text { Disinfection by chemical treatment auto- } \\
\text { claving/ microwaving and mutilation/ } \\
\text { shredding }\end{array}$ \\
\hline No. 8 & $\begin{array}{l}\text { Liquid Waste i.e. waste generated from laboratory and washing, cleaning, } \\
\text { house-keeping and disinfecting activities }\end{array}$ & $\begin{array}{l}\text { Disinfection by chemical treatment and } \\
\text { discharge into drain }\end{array}$ \\
\hline No. 9 & Incineration Ash i.e. ash from incineration of any biomedical waste & Disposal in municipal landfill \\
\hline No. 10 & $\begin{array}{l}\text { Chemical Waste i.e. chemicals used in production of biological, chemicals used } \\
\text { in disinfection, as insecticides, etc. }\end{array}$ & $\begin{array}{l}\text { Chemical treatment and discharge into } \\
\text { drains for liquids and secured landfill for } \\
\text { solids }\end{array}$ \\
\hline
\end{tabular}




\subsection{Effects of biomedical waste}

The improper biomedical waste management causes severe environmental complications that in turn causes air, water and land pollution. The pollutants that cause impairment can be grouped as biological, chemical and radioactive. The radioactive waste produced as part of bio-medical waste may have severe effects on air, radioactive, land, human health and environment (Mehta, 1998), as detailed below:

\subsubsection{Air Pollution}

Air pollution may be in indoors and outdoors atmosphere, and it can be caused by pathogens. If the Biomedical waste is transported without pre-treatment or if it is dumped in open areas, pathogens can easily transfer into the atmosphere. Chemical pollutants generate outdoor air pollution due to two major sources i.e. open burning and incinerators. Open to atmosphere burning of biomedical waste is the most harmful practice and causes respiratory diseases.

\subsubsection{Water Pollution}

The liquid waste generated by sewerage system also causes water pollution, if not treated properly (Patil \& Shekdar, 2001). Water pollution affects the various parameters such as $\mathrm{pH}, \mathrm{BOD}, \mathrm{DO}, \mathrm{COD}$ etc. There exists cases where dioxins are testified from water bodies near incinerator plants, and come in the water body from the air (Rao et al., 2008; Ravikant et al., 2002).

\subsubsection{Land Pollution}

Bio-medical waste causes soil pollution due to contagious waste, chemicals, discarded medicines, ashes, etc. Dense metals such as cadmium, lead, mercury etc. present in waste can be absorbed by plants and after that, enters the agri-food chain. Nitrates and phosphates prevailing in leachates from landfills are also the other pollutants. Too much volume of trace nutrients and others containing dense metals in soil are hazardous to crops and also to animals and human beings (Rao et al., 1994). Reducing the waste and disposing off with pre-treatment on land are the ways of eradicating the soil pollution (Sandhu et al., 2003).

Hence, this study has been carried out in the Northwest Delhi region in India, to investigate the awareness level and practices regarding biomedical waste management among medical practitioners. Section 1 of this paper provides the comprehensive background of 'biomedical waste management' detailing the emergence of the theme; Section 2 is the literature review. Section 3 includes materials and methods detailing sampling, survey instrument and analysis; while Section 4 discusses the results and findings of study. Finally, Section 5 is the conclusion part of the study.

\section{Literature review}

Oli et al. (2015) revealed that the accessibility of material for waste segregation and the existence of infection control committee in hospitals is generally low and unsatisfactory. Alam et al. (2014) concluded that the level of awareness about BMW in medical industry needs to be risen to ensure spontaneous participation of proper biomedical waste management. Joseph et al. (2015) discussed that the training, daily inspections, involvement of hospital managers and regular assessments are essential to improve the biomedical waste management. Basu et al. (2012) assessed the awareness level of BM waste management among low-ranking doctors and suggested the training programs and monitoring at fixed time intervals with special highlighting on low-grade doctors (Silva et al., 2005). Arshad et al. (2011) observed that hospital staff are not using safety measures in the treatment of waste disposal or laboratory testing for infectious diseases. Sharma (2010) outlined the gap between BMW guidelines 
and scarce state of implementation and awareness in practice. Sreegiri (2009) found that 33\% staff in a tertiary level hospital in Visakhapatnam (India) were not aware of where the waste from hospital was finally treated and disposed-off. Alagöz and Kocasoy (2008) found incorrect handling of BMW and lack of proper arrangements for carrying the healthcare waste to final disposal sites (Singh, 2004). Bdour et al. (2007) examined the BMW practices in northern part of Jordan and found that there were no defined methods for handling and discarding the biomedical wastes. Moreover, there were no precise regulations or plans for segregation or classification of these wastes (Tudor et al., 2005). Al-Khatib (2006) assessed the safety among wardens in Palestinian hospitals and its relation with the medical waste management in hospitals, and noted that the level of safety at work was below standard requirements for most workers.

Silva et al. (2005) revealed that the health care facilities in South Brazil helped segregation of group 'A' wastes, and low care was taken to different wastes, which were generally accomplished without a position for recycling and collection from the municipal collection system (WHO, 2005). Tudor et al. (2005) suggested to make improvements in the overall organizational infrastructure and enlarged localized control, and suggested that waste managing programs should be a part of academic course for all healthcare workers (Xie \& Zho, 2013). Askarian et al. (2004) found unsatisfactory training of people, inadequate personal caring apparatus and lack of knowledge about the use of safety equipment in a hospital in Iran. Authors suggested the compilation of rules and the formation of standards, along with effective training for personnel (Xie \& Zho., 2009). Patil and Pokhrel (2001) conducted a study to assess waste management system and quantitatively estimated the amount of non-infectious and infectious waste produced in different sections. Authors recommended that infectious waste must be collected separately from the laboratory, must go directly to the incinerator and should not be transported through the patient area. It was also concluded that the mandatory initial training program should be conducted for all new hospitals staff to become familiar with the operating procedures performed in hospital. Kishore et al. (2000) conducted a study in New Delhi on teachers in government dental institutions and concluded that there exists the lack of knowledge and awareness about the risks of waste, rules and personnel management in healthcare.

\section{Materials and Method}

\subsection{Sampling}

In order to assess the awareness level about biomedical waste management, a descriptive cross-sectional study has been commenced among the medical practitioners in Northwest Delhi region in India. The study has been carried out by using of a scientific \& structured questionnaire with closed-ended questions, which was distributed to 320 staff members. The study population included 16 hospital waste management team, 81 doctors, 92 nursing staff, 49 laboratory technicians and 73 waste handlers

(cleaners and maintenance personnel). Three doctors, four nursing staff and two lab technician did not complete Questionnaire; therefore, 311 subjects participated in the study. Confidentially of the participants was maintained. Under the supervision of one associate professor and one $\mathrm{PhD}$ scholar, the data was collected during the months of February and March 2016.

\subsection{Survey Instrument}

The study for collecting data was approved by each medical superintendent in all hospital in written. The questionnaire comprised of 38 questions that were designed to obtain the evidence about knowledge of BMW generation and its management practices. The questions were grouped under three set- first set of the questions was for the hospital management, second set of the questions was for the doctors, nurses, and lab technicians and third set was for the waste handlers. After enlightening the objective of the study, the questionnaire was administered to each medical practitioner. 


\subsection{Analysis}

To facilitate the entry process, the complete questionnaires were separated into group by stats. Data from the surveys were analyzed using descriptive statistical analysis. The collected data can be de described by graphical representation and percentage. The reliability of the questionnaire has been done through Cronbach alpha (0.712) in SPSS (Table 2 and Table 3).

Table 2

Item Statistics

\begin{tabular}{cccc}
\hline Sr. No. & Mean & Std. Deviation & $\mathrm{N}$ \\
\hline 1 & 1.1875 & 0.40311 & 16 \\
2 & 1.1875 & 0.40311 & 16 \\
3 & 1.1250 & 0.34157 & 16 \\
4 & 1.2500 & 0.57735 & 16 \\
5 & 1.3125 & 0.70415 & 16 \\
6 & 1.2500 & 0.57735 & 16 \\
7 & 1.1875 & 0.54391 & 16 \\
8 & 1.1875 & 0.40311 & 16 \\
9 & 1.1875 & 0.54391 & 16 \\
10 & 2.2500 & 0.68313 & 16 \\
11 & 1.7500 & 0.77460 & 16 \\
12 & 1.3750 & 0.50000 & 16 \\
13 & 1.8125 & 0.54391 & 16 \\
14 & 1.1875 & 0.54391 & 16 \\
15 & 1.9375 & 0.44253 & 16 \\
\hline
\end{tabular}

Table 3

Scale Statistics

\begin{tabular}{cccc}
\hline Mean & Variance & Std. Deviation & N of Items \\
\hline 22.7500 & 15.400 & 3.92428 & 16 \\
\hline
\end{tabular}

\section{Results and discussion}

For the question about the 'Segregation of waste at the source', $81.25 \%$ says 'Yes', they were segregating the biomedical waste at source, $12.5 \%$ says 'No', they were not segregating the biomedical waste at source. $6.25 \%$ did not express any comment on the query. It is also written in the (Handling and Management) rules 1998 that all healthcare facilities should segregate BMW at source, but still approx. $13 \%$ did not segregate the Biomedical waste at source (Fig. 1).

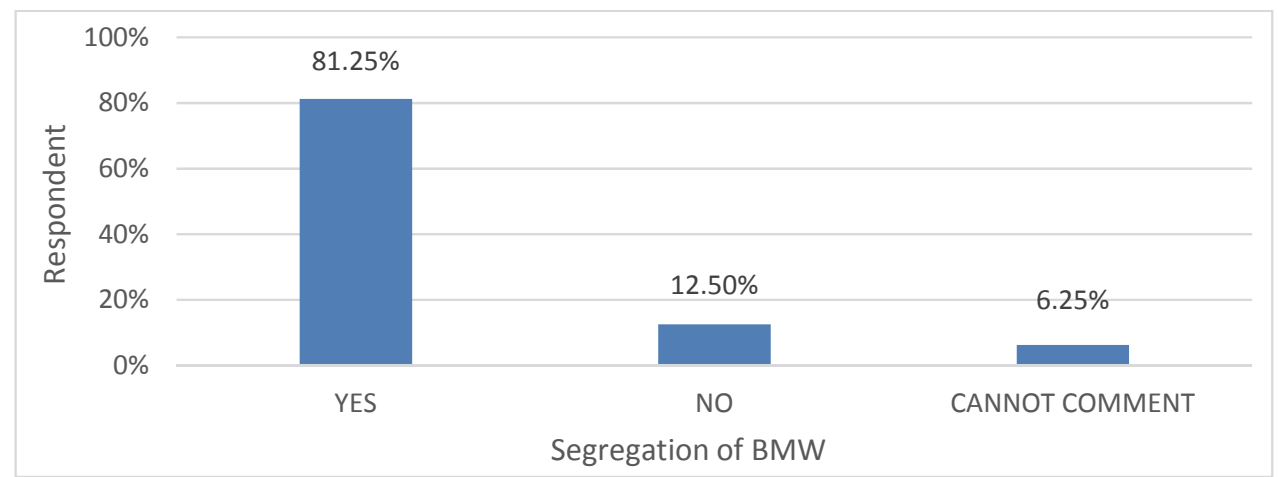

Fig. 1. Segregation of Biomedical waste at Source 
Total of 16 BMW management team responded the question about the percentage of infectious waste among total waste. About $50 \%$ of them says that the $10-20 \%$ waste was infectious, $31.25 \%$ says that $30-40 \%$ waste was infectious, $12.5 \%$ says that $50-60 \%$ waste was infectious and $6.25 \%$ says that 70 $80 \%$ waste was infectious among the total waste (Fig. 2).

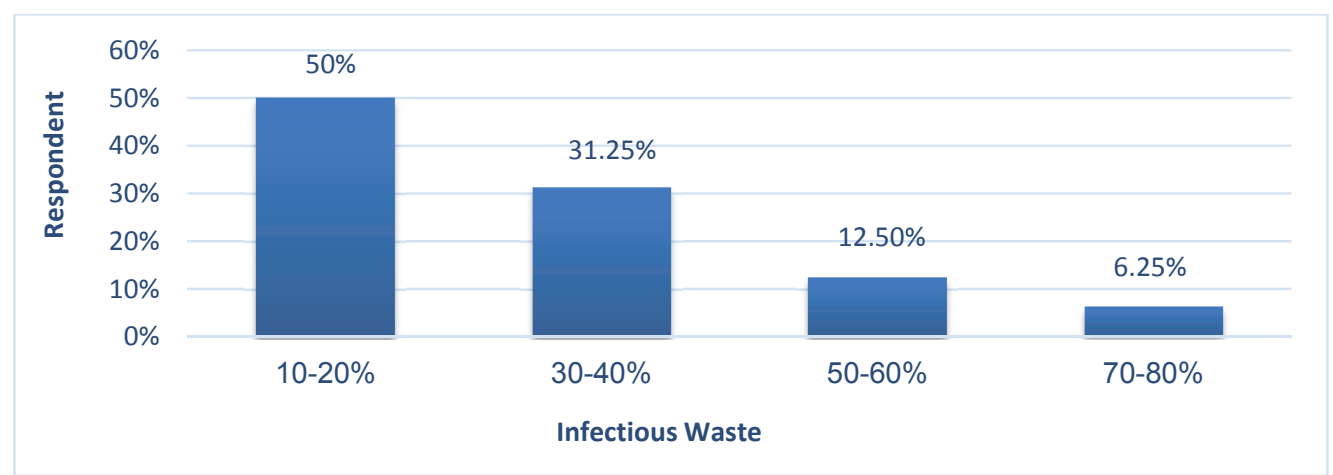

Fig. 2. Infectious waste among total Waste

Segregation of biomedical waste is the first step in management of BMW. It is also written in the (Handling and Management) rules 1998 that all health care facilities have to segregate BMW at source but still 19\% did not segregate the biomedical waste at source. When a question is asked about the segregation of waste at the source, $81.25 \%$ says that they were segregating the biomedical waste at source, $12.5 \%$ says that they were not segregating the biomedical waste at source and $6.25 \%$ did not comment on this (Fig. 3).

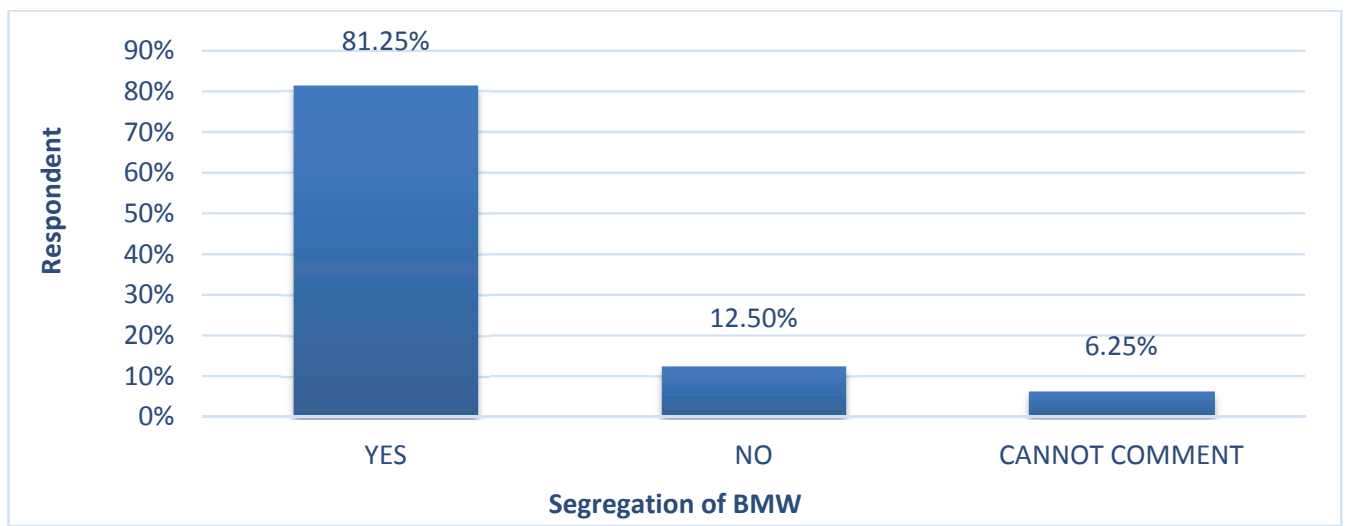

Fig. 3. Segregation of BMW

Results show that only $56.25 \%$ health care facilities used needle cutter to destroy the used needle, $37.5 \%$ did not use needle cutter to cut the needle and $6.25 \%$ did not want to comment on this (Fig. 4).

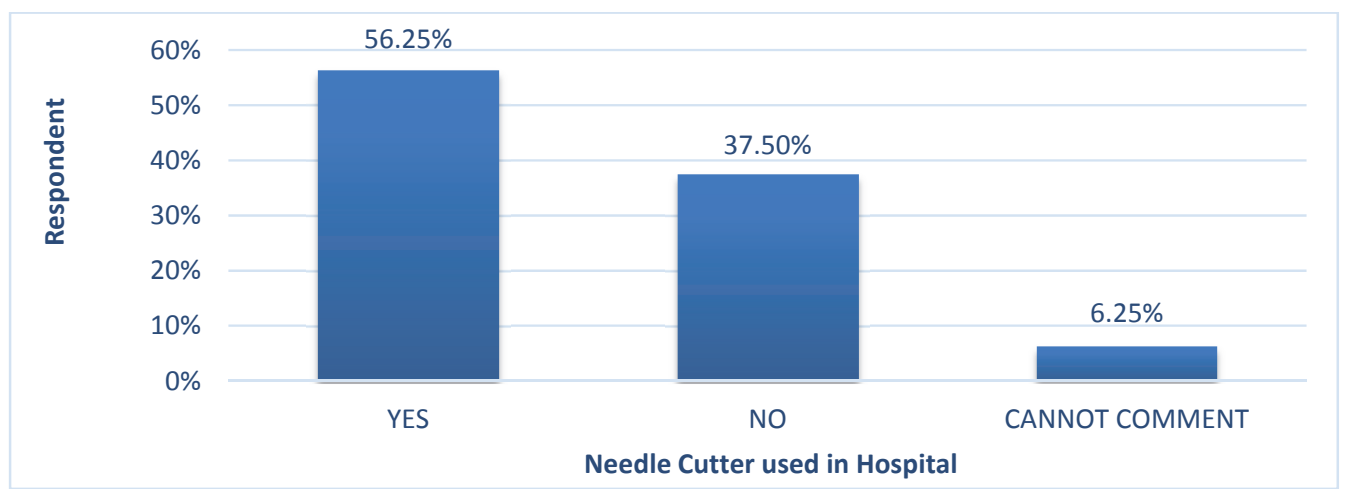

Fig. 4. Use of Needle Cutter 
For the query of 'Storing Biomedical waste beyond 48 hours', it was surprising to see that only $69 \%$ did not store the Biomedical waste beyond 48 hours, still $12.5 \%$ store the biomedical waste beyond 48 hours and $18.75 \%$ did not want to comment on this (Fig. 5).

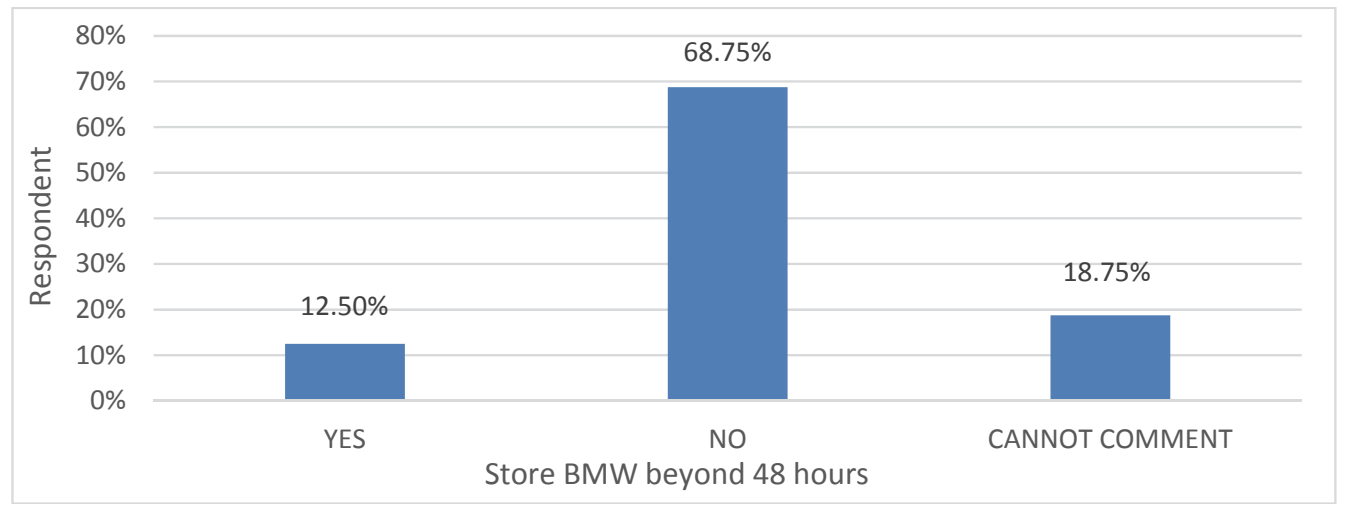

Fig. 5. Storage of Biomedical waste beyond 48 hours

Further, the question on 'Does the vehicle which collect the Biomedical waste have GPS system?', it was amazing to see that the only $6.25 \%$ knew that the vehicle which collect the Biomedical may have GPS system, $43.75 \%$ did not know that the vehicle had GPS system or not and 50\% says that they did not want to comment on this question (Fig. 6).

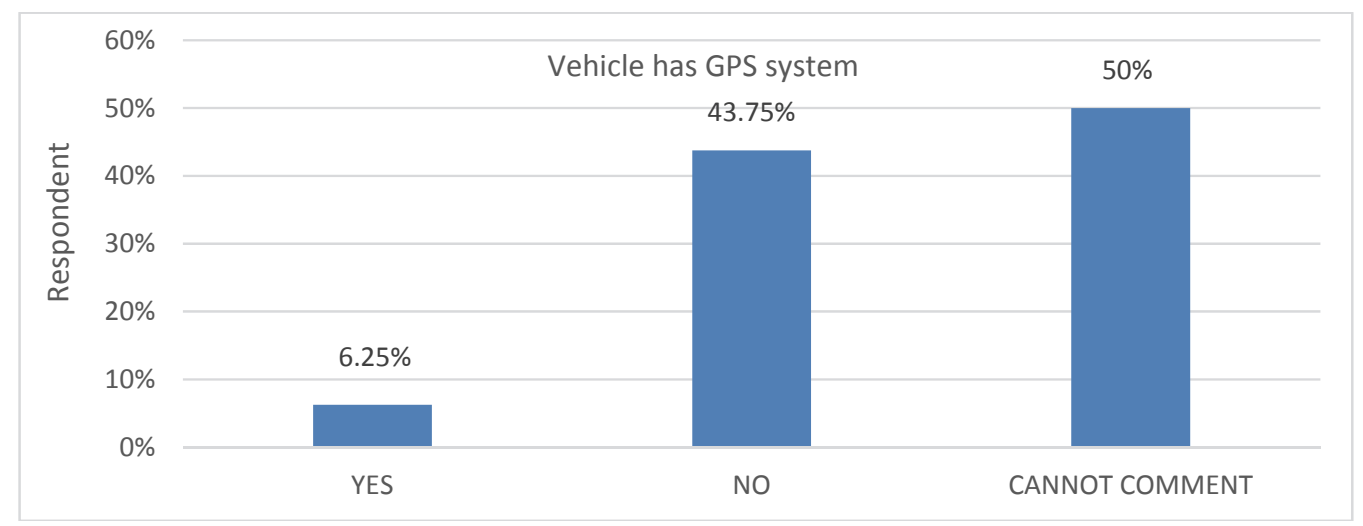

Fig. 6. GPS system in BMW Vehicles

It is very necessary to see that the vehicle which collect the Biomedical waste has GPS system or not because if a vehicle does not have GPS system it means the collector of Biomedical waste is free to reach at treatment and disposal site or dump at anywhere in the way. This study also revealed that only $50 \%(\mathrm{n}=16)$ shred the Biomedical waste before disposal, $37.5 \%$ says that they do not shred the Biomedical waste before disposal and $12.5 \%$ says that they do not want to comment on this. Some Biomedical waste needs shredding before disposal because after shredding, the disposal of the waste becomes easy. Shredding is a process to cut the biomedical waste into small pieces for easily transportation and treatment of Biomedical waste (Fig. 7). 


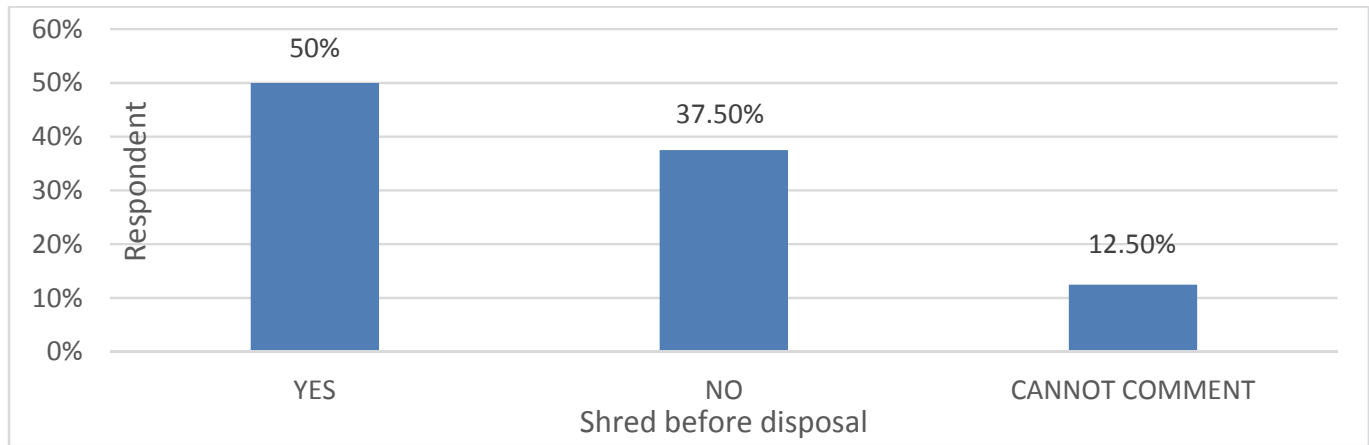

Fig. 7. Shred the Biomedical waste before Disposal

Training of waste handlers and particulars regarding risk involved in waste handling are represented in Table 4.

Table 4

Training regarding risk involved in waste handling

\begin{tabular}{cccc}
\hline $\begin{array}{c}\text { Sr. } \\
\text { No. }\end{array}$ & Training and other particulars & $\begin{array}{c}\text { No. of } \\
\text { users }\end{array}$ & $\%(\mathrm{n}=73)$ \\
\hline 1 & Received special training in bio-medical waste handling & 68 & 93.15 \\
2 & Any injury/puncture/infection in the past 6 months & 23 & 31.5 \\
3 & Accident reported to higher authority & 23 & 100 \\
4 & Vaccinated to protect against many infectious diseases & 57 & 78.08 \\
\hline
\end{tabular}

Out of 73 waste handlers, it was very good to see when a question was asked to waste handlers about the use of personal protective gears, all waste handlers $(n=73)$ were using gloves, $63 \%$ waste handlers were using apron, $52 \%$ were using long boot, $98.63 \%$ were using mask and approx. $22 \%$ waste handlers were using eye shield while handling Biomedical waste (Fig. 8).

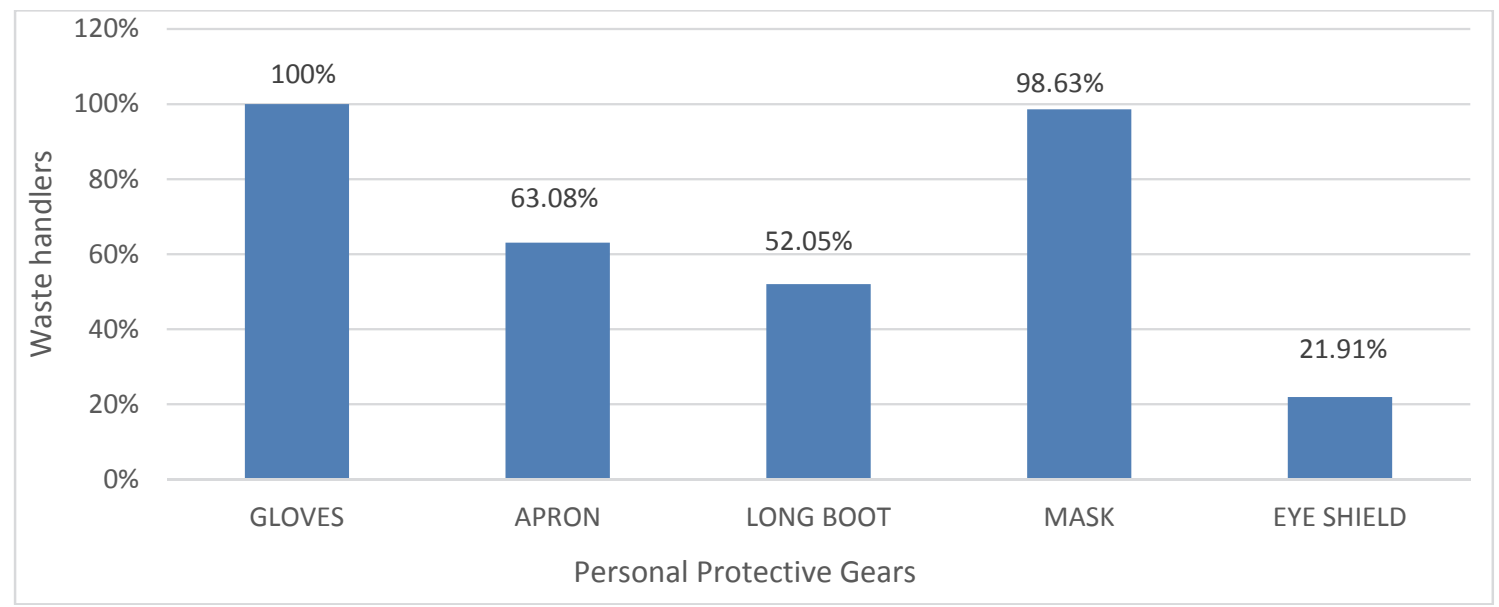

Fig. 8. Use of PPGs while handling Biomedical waste

This study revealed that only $78 \%$ waste handlers had vaccinated to protect against many infectious diseases and 22\% waste handlers had not vaccinated to protect against many infectious diseases (Fig. 9). Vaccination of waste handlers against infectious diseases is very important because it protect from infection due to needle stick injury. 


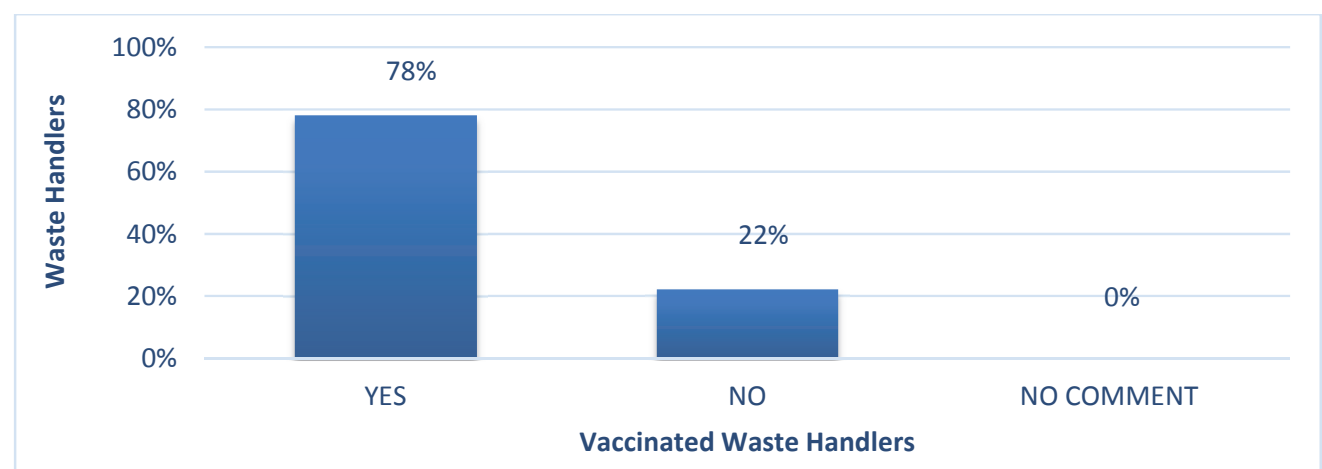

Fig. 9. Vaccination of waste management

This study revealed that almost all doctors, nurses and lab technician destroyed the used needle immediately. The statistics shows that 95\% doctors, 94\% nurses and 93\% lab technician destroy the used needle (Fig. 10). While some responses were not destroying it and others responded as somewhat (SW).

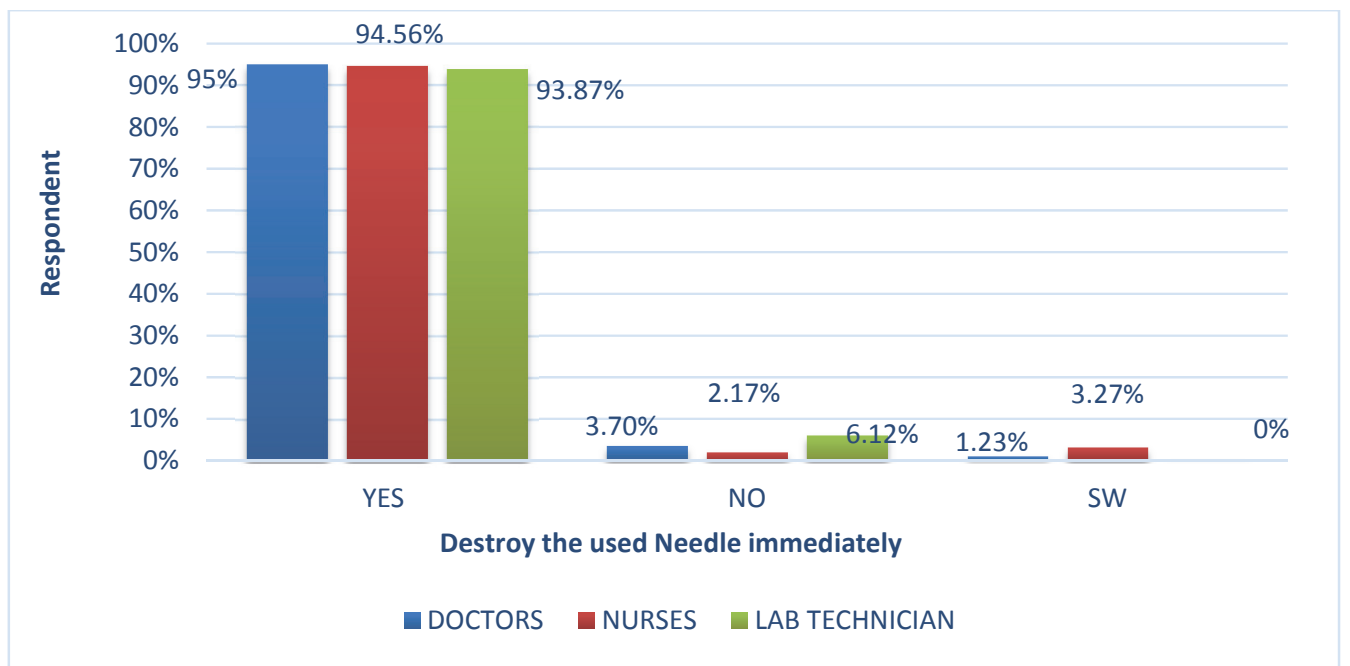

Fig. 10. Destroying the used Needle

In this study, it was revealed that the $91.35 \%$ doctors, $97.82 \%$ nurses and $87.75 \%$ lab technician knew that biomedical waste had negative effect on people's health but only $39.50 \%$ doctors, $17.39 \%$ nurses and $32.65 \%$ lab technician had knowledge about the type of effect biomedical waste may cause on human health (Fig. 11).

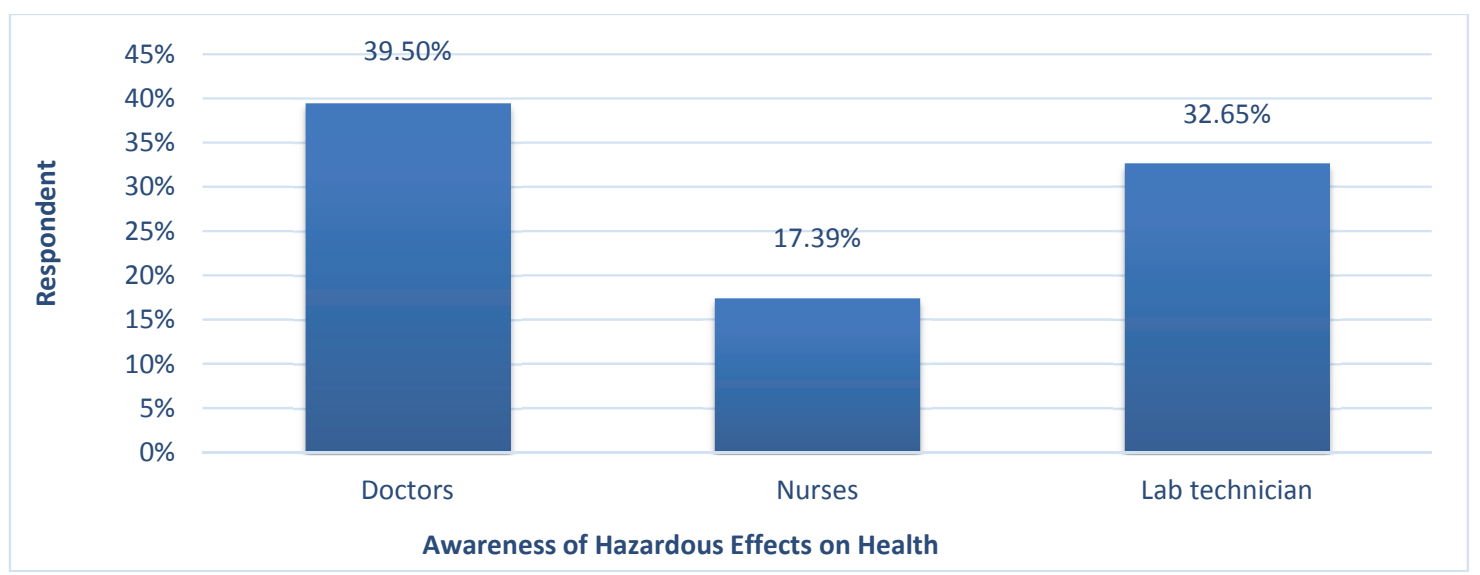

Fig. 11. Effects of Hazardous on Health 
This study also revealed that out of 222 respondents, 81 doctors, 92 nurses and 49 labs technician responded the questionnaire from 30 health care facilities. It was surprising to see that only $53 \%$ of doctors, nurses and lab technician gave correct answer when a question was asked about the biomedical waste to be autoclaved, disinfected (Fig. 12). So, the doctors, Nurses and lab technicians must have knowledge of color coding of waste categories.

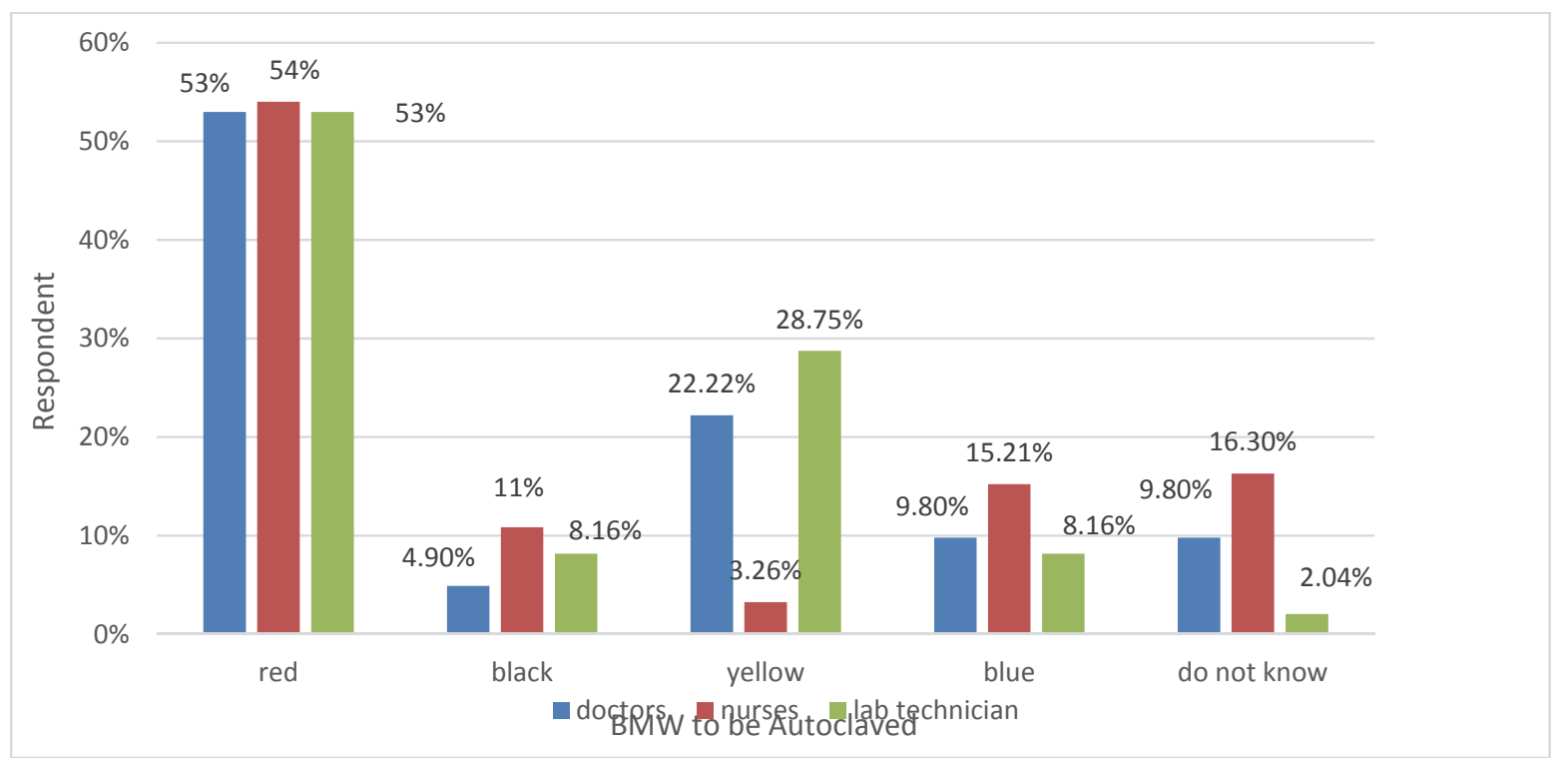

Fig. 12. Color code of biomedical waste to Autoclaved, Disinfected

Knowledge of nurses compared with the doctors and lab technician was good when a question was asked about on whether they put plastic waste in yellow bins. $89 \%$ nurses, $65 \%$ doctors and $71 \%$ lab technician gave correct answer (Fig. 13).

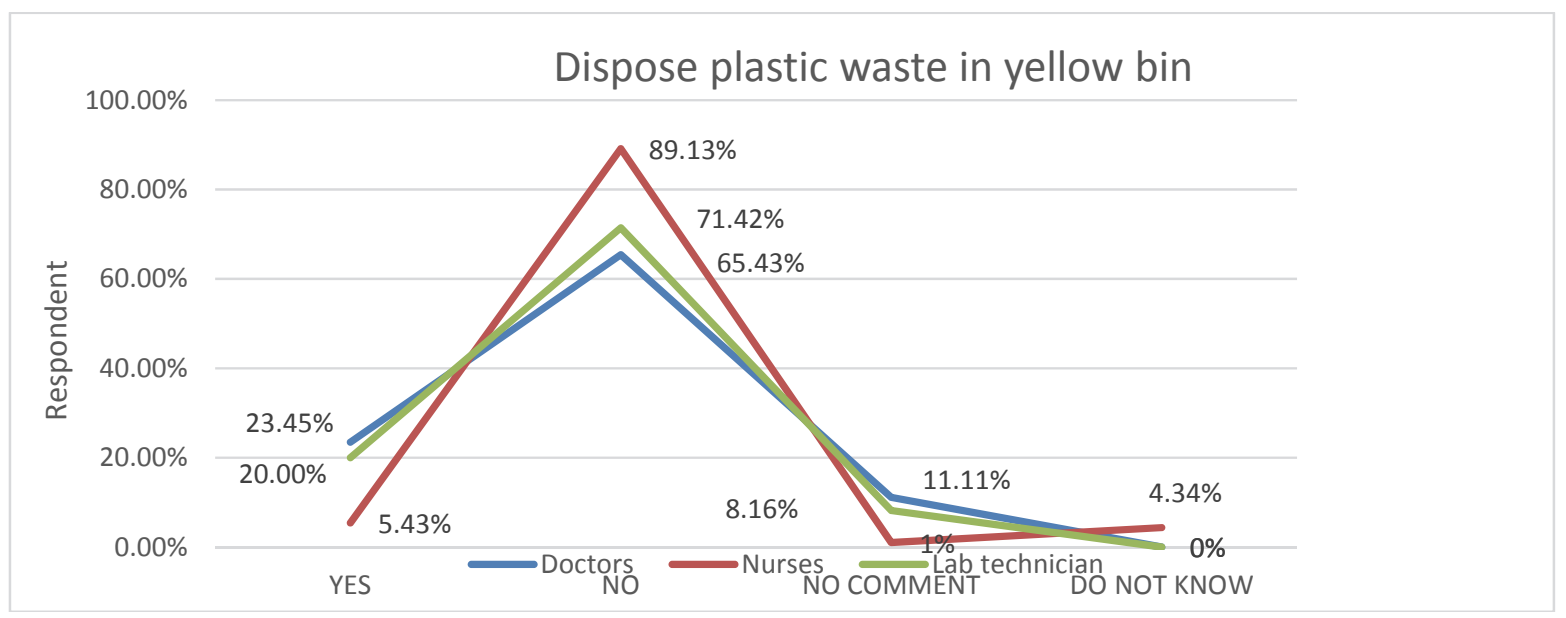

Fig. 13. Disposal of plastic waste in Yellow bins

\section{Conclusion}

It can be concluded that there was a lack of knowledge and awareness about biomedical waste generation, its threats, disposing off rules and management among most of the healthcare personnel in healthcare facilities in Northwest Delhi region in India. Poor and ineffective segregation and transportation system was causing severe risk of health diseases to the society. Even though, the knowledge and awareness level about needle stick injury was highly adequate, healthcare personnel were in a dearth of the hazards and toxic materials. Appropriate biomedical waste management was the concern 
acknowledged by both government agencies and the non-government organizations. Thus, the suitable execution of protective methods, written policies, training programs, regular audits may subsidize the healthcare personnel, hospital staff, patients and the community to the risk of biomedical hazards. Finally, it is recommended that the hospital waste management team conduct awareness \& training program at regular interval of time.

\section{References}

Acharya, D. B. \& Singh, M. (2000). The Book of Hospital Waste Management. Minerva Press, New Delhi, 15-47.

Alam, O., Uddin, M. S. \& Hossain, M. M. (2014). Silent killing through exposure to healthcare waste under the current management practices in Chittagong. Proceedings of Int. Conf. on Mechanical Engg. \& Renewable Energy, Chittagong, Bangladesh, 1-3 May, 2014.

Alagöz, A. Z. \& Kocasoy, G. (2008). Improvement and modification of the routing system for the healthcare waste collection and transportation in Istanbul. Waste Management, 28(8), 1461-1471.

Al-Khatib, I. A. (2006). Occupational safety of cleaning personnel in Palestinian district hospitals. Eastern Mediterranean Health Journal, 12(5), 637-652.

Almuneef, M. \& Memish Z. A. (2003). Effective medical waste management: it can be done. American Journal of Infection Control, 31(3), 188-192.

Arshad, N., Nayyar, S., Amin, F. \& Mahmood, K. T. (2011). Hospital waste management: a review article. Journal of Pharmaceutical Sciences and Research, 3(8), 1412-1419.

Ashtekar, S., Mankad, D. \& Raimane, K. (2004). Child mortality determinant in three backward districts of Maharashtra, Nandurbar, Jalna and Yavatmal. Mumbai: Indira Gandhi Institute of Development Research. Study report by BharatVaidyaka Sanstha, 1-15.

Askarian, M., Vakili, M. \& Kabir, G. (2004). Hospital waste management status in university hospitals of the Fars province, Iran. International Journal of Environmental Health Research, 14, 295-305.

Basu, M., Das, P. \& Pal, R. (2012). Assessment of future physicians on biomedical waste management in a tertiary care hospital of West Bengal. Journal of Natural Science, Biology and Medicine, 3(1), $38-42$.

Bdour, A., Altrabsheh, B., Hadadin, N. \& Al-Shareif M. (2007). Assessment of medical wastes management practice: a case study of the northern part of Jordan. Waste Management, 27(6), 746-759.

Chitnis, V., Patil S. \& Chitnis, D. S. (2000). Hospital Effluent: A source of multi drug resistant bacteria. Current Science, 79(7), 989-991.

Government of India, Ministry of Health and Family Welfare (MoHFW). (2002). National Guidelines on Hospital Waste Management Based upon the Bio-Medical Waste (Management and Handling) Rules. New Delhi: MoHFW.

Joseph, L., Paul, H., Premkumar, J., Paul, R. \& Michael, J. S. (2015). Biomedical waste management: Study on the awareness and practice among healthcare workers in a tertiary teaching hospital. Indian Journal of Medical Microbiology, 33, 129-131.

Kishore, J., Goel, P., Sagar, B. \& Joshi, T. K. (2000). Awareness about biomedical waste management and infection control among dentists of a teaching hospital in New Delhi. Indian Journal of Dental Research, 11(4), 157-161.

Mehta, G. (1998). Hospital Waste Management, National Guidelines (Draft) prepared for GOI/WHO project, Lady Harding Medical College and Associated Hospitals, New Delhi.

Patil, A. D. \& Shekdar, A. V. (2001). Healthcare waste management in India. Journal Environment Management, 63(2), 211-220.

Rao, P. H. (2008). Report: Hospitals waste management awareness and practices: a study of three states in India. Journal of Waste management, 26(3), 297-303.

Rao, S. K. M. \& Garg, R. K. (1994). A study of Hospital Waste Disposal System in Service Hospital. Journal of Academy of Hospital Administration, 6(2), 27-31.

Ravikant, C. V., Jaiswal, S. P., Vaidya, K. \& Chitnis, D. S. (2002). Effluent Treatment Plant: Why and How? Journal of Academy of Hospital Administration, 14(1), 33-37. 
Sandhu, T. S. \& Singh, N. (2003). A Hazard Going Unnoticed - Biological Waste is a Threat to the Community at Large. The Tribune online edition, Chandigarh, India, June 30, 2003 (accessed online on July, 18, 2017).

Sharma, S. (2010). Awareness about Bio-medical waste management among healthcare personnel of some important medical centers in Agra. Int. Journal of Environmental Science and Development, 1(3), 251-255.

Silva, C. E., Hoppe, A. E., Ravanello, M. M. \& Mello, N. (2005). Medical waste management in the south of Brazil. Waste Management, 25(6), 600-605.

Singh, R. (2004). Biomedical Waste. Toxics Link Fact Sheet, 20.

Sreegiri, S. \& Krishna, B. G. (2009). Biomedical waste management in a tertiary level hospital in Visakhapatnam. Journal of Community Medicine, 5, 1-6.

Tudor, T. L., Noonan, C. L. \& Jenkin, L. E. (2005). Healthcare waste management: a case study from the National Health Service in Cornwall, United Kingdom. Waste Management, 25(6), 606-615.

W.H.O. (2005). Management of Solid Healthcare Waste at Primary Healthcare Centers- A DecisionMaking Guide. W.H.O., Geneva.

Xie, R., Li, W., Li, J., Wu, B. \& Yi, J. (2009). Emissions investigation for a novel medical waste incinerator. Journal of Hazardous Materials, 166, 365-371.

Xie, Y. \& Zhu, J. (2013). Leaching toxicity and heavy metal bioavailability of medical waste incineration fly ash. Journal of Material Cycles and Waste Management, 15, 440-448.

Yan, H. J., Peng, Z. \& Lu, Y. S. (2007). Degradation of PCDD/Fs by Mechanochemical treatment of fly ash from medical waste incineration. Journal of Hazardous Materials, 147(1-2), 652-657.

Yan, H. J., Zhu, M. H. \& Jiang, G. X. (2009). Analysis of volatile species kinetics during typical medical waste materials pyrolysis using a distributed activation energy model. Journal of Hazardous Materials, 162(2-3), 646-651.

Yan, M., Li, D. X. \& Lu, Y. S. (2011). Persistent organic pollutant emissions from medical waste incinerators in China. Journal of Material Cycles and Waste Management, 13, 213-218.

Yang, C., Peijun, L. \& Lupi, C. (2009). Sustainable management measures for healthcare waste in China. Journal of Waste Management, 29(6), 1996-2004.

Young, S. T., Baird, B. C. \& Pullman, M. E. (1996). POM research productivity in U.S. business schools. Journal of Operations Management, 14(1), 41-53.

Yong, Z., Gang, X., Guanxing, W., Tao, Z. \& Dawei, J. (2009). Medical waste management in China: A case study of Nanjing. Waste Management, 29(4), 1376-1382.

Zhang, H. J., Zhang, Y. H., Wang, Y., Yang, Y., Zhang, J., Wang, Y. \& Wang, J. (2013). Investigation of medical waste management in Gansu province, China. Waste Management \& Research, 31(6), 655-659.

Zhao, L., Zhang, F. S., Chen, M., Li, Z. \& Wu, D. B. (2010). Typical pollutants in bottom ashes from a typical medical waste incinerator. Journal of Hazardous Materials, 173(1-3), 181-185.

Zhao, L., Zhang, F. S., Wang, K. \& Zhu, J. (2008). Chemical properties of heavy metals in typical hospital waste incinerator ashes in China. Waste Management, 29(3), 1114-1121.

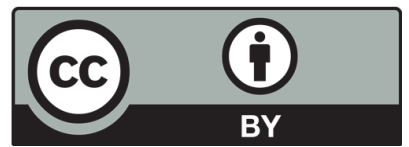

(C) 2017 by the authors; licensee Growing Science, Canada. This is an open access article distributed under the terms and conditions of the Creative Commons Attribution (CC-BY) license (http://creativecommons.org/licenses/by/4.0/). 